\title{
International Law in the Courts of the Straits Settlements
}

\author{
Kevin YL Tan ${ }^{1}$
}

\section{INTRODUCTION}

When the British colony of the Straits Settlements - comprising Penang, Malacca and Singapore - was legally created in 1824, there existed only a Court of Judicature for Prince of Wales Island (Penang). This Court had been established in 1807 by what is commonly called the First Charter of Justice $^{2}$ and its jurisdiction did not extend to the territories of Malacca and Singapore. It was only in 1826 that a Second Charter of Justice ${ }^{3}$ was issued, establishing a Court of Judicature for Prince of Wales Island, Singapore, and Malacca.

The Court of Judicature had the jurisdiction that was a cross between that of a country court and a high court in England and was presided over by a Recorder. The Court was based in Penang, with the Recorder going on circuit but later moved to Singapore when the latter outstripped Penang in commercial and strategic importance. In 1867, the Straits Settlements became a Crown Colony and its administration was transferred from Bengal to the Colonial Office in London. With this significant change, the Court of Judicature was upgraded to a superior court of record, thus becoming the Supreme Court of the Straits Settlements. Like most other colonial courts, the Straits Settlements Supreme Court had both original

1 Of the Board of Editors; LLB (Hons) (NUS); LLM, JSD (Yale). Adjunct Professor, Centre for International Law \& Faculty of Law, National University of Singapore; Adjunct Professor, S Rajaratnam School of International Studies, Nanyang Technological University.

2 Letters Patent Establishing the Court of Judicature on the Prince of Wales Island, Mar. 25 1807, 47 Geo III.

3 Letters Patent Establishing the Court of Judicature, of Prince of Wales Island, Singapore and Malacca, 27 Nov 1826, 7 Geo IV. 
and appellate jurisdiction, with final appeals going to the Judicial Committee of the Privy Council in London.

This article examines the constitution of these courts, their jurisdictions and the two dozen or so cases on international law there were decided over the 120 years of their existence. The cases examined fall to be considered under three broad headings: (a) piracy; (b) jurisdiction; and (c) sovereign immunity. In examining these cases, the following factors will be considered: (a) applicable law; (b) the use of precedents and sources; and (c) consonance with international law norms and relevance in local jurisprudence.

\section{ESTABLISHING THE COURTS \& THEIR JURISDICTION}

\section{A. The British Acquisition of Penang and the First Charter of Justice}

The British began trading in Southeast Asia from the early 1600s but did not establish a permanent trading post till 1685 when they established Fort York at Bencoolen (today's Bengkulu in Southwest Sumatra). ${ }^{4}$ Their next settlement was the Island of Penang, the cession of which was negotiated with Sultan Abdullah of Kedah in 1786. The treaty of cession was entered into between Sultan Abdullah and Captain Francis Light (representing the British) on 1 May 1791. In consideration of 6,000 Spanish dollars, ${ }^{5}$ the Sultan agreed not to allow Europeans of any other nation to settle in the territory. Initially, the island was practically uninhabited, but within three years, its population grew to about 10,000. As the population grew, it became increasingly difficult to administer law and order on the island in the absence of proper legislation to do so. This resulted in the grant of a Charter of Justice by the Crown on 25 March 1807 that established the Court of Judicature on the island. Known as the Court of Judicature of the Prince of Wales' Island, it consisted of the Governor, three Councillors and one other judge, known as the Recorder of the Prince of Wales' Island.

\footnotetext{
4 See John Bastin, The British in West Sumatra 1685-1826 (1965).

5 This was approximately equivalent to $£ 288.50$ in 1819 , or $£ 12,000$ in today’s currency.
} 
The Court had the same jurisdiction and powers of the Superior Courts in England. In the words of Sir Peter Benson Maxwell R: ${ }^{6}$

The whole of the Charter ... gives to the Court the powers of the Superior Courts of Law and Equity at Westminster, to be exercised as far as circumstances admit, without stating or leaving any room for presuming that it was intended that those powers should be exercised otherwise than in the same manner and under the same rules and principles as they are exercised in England. ${ }^{7}$

\section{B. Singapore, Malacca and the Second Charter of Justice 1826}

European involvement in Malacca began early in the $16^{\text {th }}$ century with the Portuguese conquest of the port in 1511. It remained in Portuguese hands till 1641 when they were displaced by the Dutch. In 1795, when Holland was overrun by the French during the Napoleonic Wars, the Prince of Orange ordered that all his overseas possessions be surrendered to the British for "safekeeping." As such, Malacca was governed by the British from 1795 to 1818 . In 1826, following the British Parliament's ratification of the Anglo-Dutch Treaty of 1824, the Dutch permanently surrendered Malacca to the British in exchange for Bencoolen in Southwest Sumatra.

The British first established a "factory" or trading post at Singapore in February 1819, following a Treaty of Friendship and Cooperation signed between Thomas Stamford Raffles of the British East India Company and Sultan Hussein of Johor. In 1824, the Sultan ceded the island to the British, ${ }^{8}$ and it joined Malacca and the Prince of Wales' Island to form the Straits Settlements. ${ }^{9}$

As the 1807 Letter Patent (First Charter of Justice) did not extend beyond Penang, a new Charter of Justice had to be issued to cover Singapore

6 Sir Peter Benson Maxwell (1817-1893) served as Recorder of Penang from 1856 to 1866 and Chief Justice of the Straits Settlements from 1867 to 1871.

$7 \quad$ Regina v. Willans, [1858] 3 Ky 16.

8 Treaty of Friendship and Alliance between the Honourable East India Company, and the Sultan and the Temenggong of Johore dated 2 Aug. 1824.

9 This was effected by the passage of the Transfer of Singapore etc Act, 5 Geo. IV c. 108 under which Singapore and Malaccca were transferred to the control of the East India Company, and by $39 \& 40$ Geo. III c. 79 under which these territories were placed under the jurisdiction of the Supreme Court of Judicature in Fort 
and Malacca and this was done by a second Letter Patent which is more commonly known as the Second Charter of Justice. This Charter was granted on 27 November 1826 and arrived in the Straits in 1827. Under the Charter, a Court of Judicature was created for all three territories with

such jurisdiction and authority as our Court of King's Bench and our Justices thereof, and also as our High Court of Chancery and our Courts of Common Pleas and Exchequer, respectively ... have and may lawfully exercise within ... England, in all civil and criminal actions and suits, and in matters concerns the revenue, and in the control of all inferior courts and jurisdictions, as far circumstances will admit.

In criminal matters, the Court was to

administer criminal justice in such or the like manner and form, or as nearly as the condition and circumstance of the place and the persons will admit of, as our courts of Oyer and Terminer and Gaol Delivery do or may, in ... England, due attention being had to the several religions, manners and usages of the native inhabitants.

The Court of Judicature was a single-level colonial court with no court of appeal. The only appeal was to the King-in-Council or Queen-in-Council.

It should be noted that the East India Company's only territorial acquisitions in the Malay peninsula remained the three Straits Settlements territories till 1874 . Prior to 1874 , the British adopted a policy of nonintervention in the politics of the Malay states and thus recognised each of the Malay states as sovereign territories. It was only with the coming to power of the Conservatives in 1874 that an aggressive imperial policy was adopted, leading to the implementation of the Residency system which brought four Malay states under British control as the Federated Malay States: Perak, Selangor, Negeri Sembilan, and Pahang. ${ }^{10}$ These states formed a separate legal entity - the Federated Malay States - under international law. The remainder of the Malay States - Johor, Kedah, Kelantan, Perlis, and Terengganu - also received British protection but did not federate into

William in Bengal. The transformation of the Straits Settlements from a presidency into a Crown Colony was effected by the Government of the Straits Settlements Act 1866, 29 \& 30 Victoria c 115, by the British Parliament.

10 See Emily Sadka, The Protected Malay States, 1874-1895 (1968); Eunice Thio, British Policy in the Malay Peninsula, 1880-1910 (1969). 
a single sovereign entity and were collectively referred to as the Unfederated Malay States. ${ }^{11}$

\section{THE LACK OF ADMIRALTY JURISDICTION}

Both the First and Second Charters of Justice suffered a major deficiency - the courts they created had no admiralty jurisdiction. This meant that the Court of Judicature had no way of dealing with acts of piracy or crimes committed on the high seas or even in the colony's territorial waters. The omission of admiralty jurisdiction was more than an administrative oversight. Up till 1887, there existed in England, a separate and distinct High Court of Admiralty under the charge of the Lord High Admiral. ${ }^{12}$ This anomaly was a product of history. A court exercising jurisdiction over maritime matters came into existence sometime between 1340 and $1357^{13}$ and during this time, the common law courts ceased to hear maritime cases. From about 1360, the sea coast of England and Wales was divided into 19 districts, each of which was under the control of a Vice-Admiral of the Coast, and they all represented the Lord High Admiral.

Sir John de Beauchamp was appointed the first Admiral of all the English fleets in 1360 and his responsibility extended to protecting the coasts, administering maritime justice, collecting payments due the Crown, and suppressing piracy. This gave him jurisdiction over all disputes arising from any of these activities ${ }^{14}$ and extended to all criminal and civil matters as well. His criminal jurisdiction included piracy and murder and mayhem committed on the high seas and on ships "below the bridges of great rivers." The rise of the Admiralty Court was not welcomed by the common law

11 See generally R. O. Winstedt, Malaya: The Straits Settlements, and the Federated and Unfederated Malay States (1923).

12 On the origins and history of the Courts of the Admiralty, see Charles S. Cumming, The English High Court of Admiralty, 7 TuL. MAr. L.J. 209 (1993); Lionel H. Laing, Historic Origins of Admiralty Jurisdiction in England, 45 Мich. L. Rev. 163 (1946); F. L. Winswall JR., The Development of Admiralty Jurisdiction and Practice Since 1800: An English Study with American Comparisons (1970).

13 Laing, supra note 11, at 167.

$14 \quad I d$. at 168. 
judges who saw this as competition and a usurpation of their jurisdiction. The Court of the King's Bench thus began building up a substantial body of case law in which it also exerted admiralty jurisdiction and over time, reduced the jurisdiction of the admiralty courts but the divisions remained till the late $19^{\text {th }}$ century.

When the British East India Company settled in India and began establishing courts there, the division between common law courts and admiralty courts persisted. Mayor's Courts were established in Madras, Bombay, and Calcutta in 1726, almost 40 years after the Courts of Admiralty were established in these three presidency towns in 1683 under the $5^{\text {th }}$ Charter of the East India Company. ${ }^{15}$ It was only with the passage of the Regulating Act of 1773 that the Supreme Court at Calcutta was established. This Court, which comprised a Chief Justice and three puisne judges, had a jurisdiction that extended to all inhabitants of the states of Bengal, Bihar, and Orissa. The Supreme Courts at Madras and Bombay were established only in 1800 and 1823 respectively. ${ }^{16}$

The promulgation of Regulating Act of 1773 by the King of England paved the way for establishment of the Supreme Court of Judicature at Calcutta. The Letters Patent was issued on 26 March $17744^{17}$ to establish the Supreme Court of Judicature at Calcutta, as a Court of Record, with full power and authority to hear and determine all complaints for any crimes and also to entertain, hear, and determine any suits or actions against any of His Majesty's subjects in Bengal, Bihar, and Orissa. King George III established the Supreme Courts at Madras and Bombay on 26 December 1800 and on 8 December 1823 respectively. The Courts in these three territories did not exercise admiralty jurisdiction till 1813 when an Act was passed to this effect:

And whereas the Courts established by the said United Company have no Jurisdiction over Crimes Maritime, and Doubts have been entertained whether the Admiralty Jurisdiction of His Majesty's Jurisdiction, by reason whereof Failures of Justice may arise: Be it therefore enacted, That it shall and may be lawful for His Majesty's

15 John F. Riddick, A History of British India: A Chronology 185 (2006).

16 For a brief account of the establishment of these early courts, see CJB Larby, Centenary of the High Courts of Calcutta, Bombay and Madras, 12 ICLQ 1044 (1963).

17 Letters Patent was issued on March 26, 1774. 
Courts at Calcutta, Madras, and Bombay, exercising Admiralty Jurisdiction, to take Cognisance of all Crimes perpetrated on the High Seas, by any Person or Persons whatsoever, in as full and ample a Manner as any other Court of Admiralty Jurisdiction established by His Majesty's Authority in any Colony or Settlement whatsoever belonging to the crown of the said United Kingdom. ${ }^{18}$

Even so, this grant of admiralty jurisdiction to the Indian courts did not automatically extend to the Straits Settlements. In the meantime, the situation was quite dire. Writing in 1840, John Anderson, former Secretary to the Government of the Straits Settlements noted:

Piracy prevails to an alarming extent in the vicinity of these settlements, and an Admiralty jurisdiction in the Straits is indispensable, with a view to the suppression of that barbarous practice, so detrimental to the trade of the several ports. The expense of sending offenders of that description to Calcutta for trial, as has sometimes been done, is very considerable, and punishment inflicted at so great a distance does not operate as an example of any utility of effect. ${ }^{19}$

The lack of admiralty jurisdiction was raised as early as in November 1803 by Judge John Dickens of Penang as well as by the Grand Jury. James William Norton-Kyshe, former Registrar of the Supreme Court of the Straits Settlements noted:

Admiralty Jurisdiction was thus given to the Court after the lapse of very many years and after repeated representations both by the authorities and the Grand Jury, papers from Mr Dickens bearing date $8^{\text {th }}$ November, 1803 , being also on record on the subject, the result having been that previous to the grant of Jurisdiction, the authorities had been powerless to act, the records shewing, number

1853 Geo III Cap 155, 1813: An Act for continuing in The East India Company, for a further Term, the Possession of the British Territories in India, together with certain exclusive Privileges, for establishing further Regulation for the Government of the said Territories, and the better Administration of Justice within the same, and for regulating the Trade to and from the Places within the Limits of the said Company Charter, 21 Jul 1813.

19 John Anderson, On the Administration of Justice in the British Settlements in the Straits of Malacca, and the Government of Penang, Singapore, and Malacca, XXXi Asiatic J. \& Monthly Register for British \& Foreign India, China \& Australasia (New Series) 250251 (1840). 
of prisoners charged with piracy, released for want of authority to deal with them, and in other cases, some few being sent to Calcutta for trial in the very early days, without these however, shewing any result whatever. ${ }^{20}$

Indeed, Sir Ralph Rice, Recorder of the Court of Judicature from 1817 to 1824 , told the House of Lords that while there were "a great many" cases of piracy and that admiralty jurisdiction was "very much wanted there," cases subject to admiralty jurisdiction had to be "sent up to Calcutta" since the Court did not have "the Power to interfere in any way." ${ }^{21}$

The earliest reported case demonstrating this difficulty is $R v$. Noquedah Allong \& Ors. ${ }^{22}$ This case arose in Penang where the prisoners charged and were convicted of committing murder under the common law jurisdiction of the Court of Judicature of the Prince of Wales' Island (Penang). The offence was committed on a boat within 30 yards of Batu Sembilan, a spot at the southern end of Penang Island. At the time of the offence, the boat was within view of the land, but outside the high-water mark. At the time of the murder, it was high tide and the boat was afloat. The issue before the Recorder, Sir Edmund Stanley, was whether the Court of Judicature had jurisdiction over the case:

Whether the place where the murder was committed is within the Common Law or Land jurisdiction of the Court of Prince of Wales' Island, and whether the prisoners were properly tried there, or whether they ought to be tried by the Admiralty or Sea jurisdiction?

Stanley R, citing various authorities, including Coke's Institutes, came to the conclusion that the Court of Judicature had jurisdiction:

It appears by Lord Coke, 4 Inst: on the Court of Admiralty, that those arms of the sea which run between lands which are visible from one side to the other, are within the Common Law jurisdiction, and the offences committed within those arms of the sea,

See J. W. Norton Kyshe, A Judicial History of the Straits Settlements 1786-1890, reproduced in 11(1) Malaya L. Rev. 1, 114 (1969).

21 Affairs of the East India Company: Minutes of Evidence: 11 March 1830, 62 J. of THE HOUSE OF LORDS 971-77 (1830), available at http://www.british-history.ac.uk/ report.aspx?compid=16411.

22 [1811] 1 Kyshe 1. The word "Noquedah" referred to the captain, or the most important person on board the vessel. 
are triable by the country, and not by the Admiralty jurisdiction. 2 Hawkins, on the Court of the Coroner, concurs in this doctrine. In 2 East's Crown Law, tit: Piracy, he seems to narrow the rule to those arms of the sea running inter faces terrae, where a person can see on one side what is done on the other; but he thinks that where there is a doubt, the Common Law jurisdiction ought to prevail. In Rex $v$ Coombe, 1 Leach CC, p 388, a murder committed by a shot fired from land at Southampton harbour, which killed a person in a boat one hundred yards at sea, was properly tried at the Admiralty Session: no reason is stated, nor description given of the exact locality, but perhaps by the old Statute of $15^{\text {th }}$, Richard II, cap 3 , the Admiralty has a concurrent jurisdiction with the Common Law, as to the death of a man happening in arms of the sea or in great rivers. In Rex $v$ Broadfoot, in Foster's CC, p 154, it appears the prisoner was tried at the Recorder's Court at Bristol for a murder committed some leagues at sea from Kingroad. ${ }^{23}$

Nonetheless, Stanley R felt compelled to send the case up to the Supreme Court at Calcutta for an opinion and Sir Henry Russell CJ and all the Judges at Calcutta

were of opinion that this Court had no jurisdiction over the offence, as at Common law; but the place where it was committed, was exclusively within the Admiralty jurisdiction. ${ }^{24}$

Expressing regret at this decision, Stanley R had no option but to order the prisoners to be sent to Calcutta with the several witnesses "to take their trial before the Court there, in its Admiralty jurisdiction." 25

In another case that came up before Stanley R two years later, the Court took pains to clearly delineate the distinct jurisdictions the Common Law and Admiralty. In Rex v. Lebby Cundoo \& Anor ${ }^{26}$ the accused committed armed robbery, having attacked their victims in the Kuru River (which was in the jurisdiction of Penang), and then forcing the victims to sail up the Kurau River (which is in the state of Perak and outside the jurisdiction of

$23 \quad I d$.

$24 \quad I d$.

25 Id.

$26 \quad[1813] 2$ Kyshe Cr 6. 
Penang) where two persons were murdered. Once again, Stanley R sought the opinions of not only the judges at the Supreme Court of Calcutta but also of the judges of the Supreme Court of Madras.

All the judges - with the exception of Sir William Burroughs of the Calcutta Supreme Court - were of the opinion that as the crime of robbery had been completed at Juru River even if the prisoners were forced to assist the perpetrators in carrying off the boat to Kurau, the offence was committed within the Common Law jurisdiction of the Court of Judicature and the conviction should be upheld. Burroughs J opined that the Court of Judicature would have jurisdiction if the offence was committed within the river but that the evidence suggested that the commission or completion of the offence had been outside jurisdiction. Stanley R, affirming and concurring with the Judges of India, upheld the conviction and the prisoners were accordingly sentenced to death.

Indeed, the Court of Judicature did not have such jurisdiction till 1837 when an Act was passed "granting admiralty jurisdiction to the Court of Judicature of Prince of Wales' Island, Singapore and Malacca." 27 In 1855, a Third Charter of Justice ${ }^{28}$ was promulgated to extend the jurisdiction of the Court of Judicature and to provide for an additional Recorder to be appointed for Singapore and Malacca. This last Charter specifically established the Court of Judicature as a Court of Admiralty

with full power and authority to take cognizance of, hear, examine, try, and determine all causes, civil and maritime, and all pleas of contracts, debts, exchanges, policies of assurance, accounts, charterparties, agreements, loading of ships, and all matters and contracts which, in any manner whatsoever, relate to freight or money due for ships hired and let out, transport-money, maritime

276 Wm IV Cap LIII, 13 Aug 1836. As Braddell noted:

Great inconvenience had been experienced by the Court's lack of Admiralty jurisdiction. To remedy this, the Statute $6 \& 7$ Wm IV c 53 was passed in 1836 whereby the Court was granted such jurisdiction, and Letters Patent were issued for carrying into effect the Statute on February 25 $5^{\text {th }}$, 1837. See Roland ST. JOHN Braddell, The LaW of the Straits Settlements: A Commentary 32 (1982).

28 Letters Patent Reconstituting the Court of Judicature of Prince of Wales' Island, Singapore and Malacca, in the East Indies, Bearing Date the Tenth Day of August, in the Nineteenth Year of the Reign of Victoria in the Year of Our Lord One Thousand Eight Hundred and Fifty-Five. 
usury or bottomry, or to extortions, trespasses, injuries, complaints, demands, and matters civil and maritime whatsoever, between merchants, owners, and proprietors of ships and vessels employed or used within the jurisdiction aforesaid, or between others, contracted, done, had, or commenced in, upon, or by the sea, or public rivers or ports, creeks, harbours, and places overflown within the ebbing and flowing of the sea and high-water mark, without, about, and throughout the Settlement of Prince of Wales' Island, Singapore, and Malacca, and its dependencies, the cognizance whereof doth belong to the jurisdiction of the Admiralty, as the same is used and exercised in ... England...

Beyond establishing the Court's admiralty competence, the Third Charter went further to establish the Court's jurisdiction over maritime crimes, giving it

full power and authority to inquire, hear, try, examine, and determine by the oaths of honest and lawful men, being British subjects resident in the said Settlement, all treasons, murders, piracies, robberies, felonies, maimings, forestallings, extortions, trespasses, misdemeanours, offences, excesses, and enormities, and maritime crimes whatsoever, according to the laws and customs of the Admiralty of England, done, perpetrated, or committed upon any of the high seas; and to fine, imprison, correct, punish, chastise, and reform parties guilty, and violators of the laws, usurpers, delinquents, contumacious absenters, masters of ships, mariners, rowers, fishers, shipwrights and other workmen exercising any kind of maritime affairs, according to the said civil and maritime laws, ordinances, and customs, and their respective demerits; and to deliver and discharge persons imprisoned in that behalf who ought to be delivered; and to take recognizances, obligations, stipulations, and cautions, as well to our use as at the instance of other parties, and to put the same in execution, or to cause or command them to be executed; and also to arrest, or cause or command to be arrested, according to the civil law and the ancient customs of our High Court of Admiralty in England, all ships persons, things, goods, wares and merchandises, for the premises and every of them, and for other causes whatsoever concerning the same, wheresoever they shall be met with or found ...

... shall and it is hereby empowered to take cognizance of all crimes perpetrated on the high seas by any person or persons whatsoever, in as full and ample a manner as our supreme Court of Judicature at Fort William in Bengal is now, by virtue of any Charter or Acts of Parliament, authorized to exercise any admi- 
ralty jurisdiction or as any other Court of Admiralty established by royal authority in any Colony or Settlement whatsoever belong to the Crown of the said United Kingdom. Provided Always, that the several powers and authorities herein given to the said Court to proceed in maritime causes, and according to the laws of the Admiralty as herein expressed, shall extend and be construed to extend only to such persons as, pursuant to the provisions hereinbefore contained, are and would be amenable to the said Court of Judicature of Prince of Wales' Island, Singapore and Malacca, in its ordinary jurisdiction.

The admiralty jurisdiction of the Supreme Court of the Straits Settlements was reaffirmed with the passage of the Straits Settlements Courts Ordinance $1907,{ }^{29}$ where under section 9(2), the original civil and criminal jurisdiction of the Court was to include "The jurisdiction and authority of a Colonial Court of Admiralty conferred upon it by The Colonial Courts of Admiralty Act 1890." This piece of legislation ${ }^{30}$ was passed to "amend the Law respecting the exercise of Admiralty Jurisdiction in Her Majesty's Dominions and elsewhere out of the United Kingdom.” The relevant provision, section 2(1) provides:

Every court of law in a British possession which is for the time being declared in pursuance of this Act to be a court of Admiralty, or which, if o such declaration is in force in the possession, has therein original unlimited civil jurisdiction, shall be a court of Admiralty, with the jurisdiction in this Act mentioned, and may for the purpose of that jurisdiction exercise all the powers which it possesses for the purpose of its other civil jurisdiction, and such court in reference to the jurisdiction conferred by this Act is in this Act referred to as a Colonial Court of Admiralty. Where in a British possession the Governor is the sole judicial authority, the expression 'court of law' for the purposes of this section includes Governor.

With the passage of this legislation, and by its reaffirmation by the Straits Settlements Court Ordinance, any further lingering doubt about the admiralty jurisdiction of the Straits Settlements was put to rest.

29 Ordinance No. XXX of 1907.

$30 \quad 53 \& 54$ Vic., Cap. 27. 


\section{PIRACY}

Related to the problem of admiralty jurisdiction was the scourge of piracy. ${ }^{31}$ Now having been vested with admiralty jurisdiction in 1837, the Straits Settlements Supreme Court could hear cases in which piracy was committed. ${ }^{32}$ The earliest case to come before the court in which piracy was alleged was the 1840 case of Regina v. Tunkoo Mohamed Saad \& Ors ${ }^{33}$ in which the grandson of the former Sultan of Kedah was accused of piracy. Much of this case revolved around arguments as to whether the acts of the accused were piratical acts or acts of war, and the jury acquitted them on the evidence. This time, the Court had absolutely no doubt that it had jurisdiction to try the case, especially since it involved allegations of piracy on the ground that

persons of all nations are primâ facie subject to the jurisdiction of a Court of Admiralty, for crimes committed upon the high seas against the acknowledged Law of Nations. ${ }^{34}$

Addressing the prisoners, Norris R said:

Prisoners, you have been tried of an ignominious crime - as alleged pirates, violators of the universal Law of Nations, and enemies of all mankind. The crime with which you stood charged is a capital crime, and had you been convicted, your lives would have been in jeopardy. ${ }^{35}$

This was the first instance in which the concept of universal admiralty jurisdiction was asserted in cases involving piracy jure gentium (piracy by the law of nations). The distinction between an act of piracy as determined

31 See generally, L.A. Mills, British Malaya, 1824-1867, in 1(2) J. of The Malayan Branch of the Royal Asiatic Society 214-38 (1923); Carl A. Trocki, Prince of Pirates: The Temenggongs and the Development of Johor and Singapore, 1784-1885 (1979); and Alfred P. Rubin, The Uses of Piracy in Malayan Waters, in Grotian Society Papers: Studies in the History of the LaW of Nations, 111, 111-135 (Charles Henry Alexandrowicz ed., 1968).

32 As to the Court's power to punish pirates, see the Court of Appeal decision in $R$. v. Chia Kuek Chin \& Ors. [1909] 13 S.S.L.R. 1.

33 [1840] 2 Ky. Cr. 18.

34 Id.

35 Id. 
by municipal law and by the law of nations was made all the more explicit in the case of Regina v. Mat Erat. ${ }^{36}$ In that case, the accused were charged with murder committed on the Krean River, ${ }^{37}$ which divided British territory from that of another sovereign state. As such, the case revolved around the question of whether or not this amounted to "piracy on the high seas." Mr. Justice Hackett held that the Admiralty Court had no jurisdiction over the crime as proved since it did not amount to piracy jure gentium, and the prisoner was not liable for any other offence unless he was a British subject or committed the crime on board a British vessel. ${ }^{38}$

The Court maintained this stance in the 1882 decision of Hass v. Choo Chye $H_{o}{ }^{39}$ where the appellant Chief Officer of the German steamship Picciola allegedly assaulted, beat, and kicked the respondent, the officer-incharge of the cargo on the merchant ship. The assault took place while the vessel was proceeding from Rangoon to Penang but the assault occurred on the high seas. The case was tried before a magistrate who convicted the accused and fined him $\$ 10.00$. The magistrate's decision was overturned on appeal, and Wood J held that the Court's admiralty jurisdiction did not extend to a foreigner committing a crime on a foreign ship on the high seas. ${ }^{40}$ Likewise, the criminal courts of the Straits Settlements would have no jurisdiction over a foreign subject who wilfully fails to perform his obligations under a contract signed in the Straits, but which was to be performed in a foreign land. ${ }^{41}$

The Straits Settlements Court of Appeal had occasion to consider in greater detail, what constituted "piracy jure gentium" in Regina v. Nya Abu \& Ors, ${ }^{42}$ a case which arose in 1886. In that case, the accused, who were from Aceh (and therefore of Dutch nationality), were accused of piratical acts on

$36 \quad[1872] 2$ Ky. Cr. 86.

37 This river is today known as the Kerian River or Sungei Kerian and is located in the north of the state of Perak.

38 The following cases were cited in support of this proposition: Reg. v. Lewis, 26 L.J. M.C. 104; and Reg. v. Bjorsen, 34 L.J. M.C. 180.

$39 \quad$ [1882] 3 Ky. 152.

40 See also, R. v. Low Chok \& Ors. [1893] 1 S.S.L.R. 145; and R. v. Poh Lam Tengah, [1854] 2 Ky. Cr. 74.

41 See The Attorney-General v. Wong Yew 10 S.S.L.R. 44 (1906).

42 [1885-1890] 4 Ky. 169. 
a Dutch vessel. The Court thus had to consider if it had jurisdiction to try the prisoners. Mr. Justice Wood adopted the definition of "piracy" given in Sir James Fitzjames Stephens' Digest of the Criminal Law in which he said:

Piracy by the law of nations is taking a ship in the high seas, or within the jurisdiction of the Lord High Admiral, from the possession or control of those who are lawfully entitled to it, and carrying away the ship itself or any of its goods, tackle, apparel or furniture, under circumstances which would have amounted to robbery, if the act had been done within the body of an English country. ${ }^{43}$

As this statement of the law had found endorsement in the Judicial Committee of the Privy Council in the 1873 decision of Attorney-General of Hongkong v. Kwok A Sing, ${ }^{44}$ Wood J held that the acts were indeed acts of piracy over which the court had jurisdiction.

\section{SOVEREIGN IMMUNITY}

From the outset, the Court of Judicature observed the edict that foreign sovereigns are not amendable to its jurisdiction. The earliest reported decision is the case of Sultan Omar Akamoden v. Nakodah Mohamed Cassim ${ }^{45}$ which involved Sultan Omar Akmuddin III of Sambas, an old kingdom that had been overrun by the Dutch, located on the island of Borneo. A dispute arose between the Sultan and the defendant over a contract for the sale of some chests of opium at Sambas where the disputants were both resident at the time. After the breach occurred, both parties arrived in Singapore and the plaintiff commenced this action. As it was the Sultan who commenced the action, Norris R held that even though the Sultan can lay claim to being a foreign sovereign, his commencement of the suit subjected and submitted him to the jurisdiction of the Court. ${ }^{46}$

In Abdul Wahab bin Mohomat Alli v. Sultan Alli Iskander Shah (Sultan of Johore), ${ }^{47}$ a case decided 1843, the Court recognised the distinction

43 Id. at 173, citing James Fitzjames Stephen, A Digest of the Criminal Law 64 (1877).

$44 \quad 5$ L.R.P.C. $177,199$.

45 [1841] 1 Ky. 37.

46 Id.

$47 \quad$ [1808-1884] 1 Ky. 298. 
between acts of the state and commercial acts - acta jure imperii versus acta jure gestionis. In that case, the defendant Sultan of Johore was sued on a promissory note he had given for a loan given by the plaintiff. Norris $\mathrm{R}$ cited Vattel's Treatise on the Law of Nations, Book 1, chapter 1, as authority for this distinction:

What has no affinity with his functions and character, cannot partake of the privileges which are solely derived from his functions and character. Should a minister, therefore, [as it has often been the case] embark in any branch of commerce, all the effects, goods, money and debts active and passive, which are connected with his mercantile concerns, and likewise all contests and lawsuits, to which they may give rise, fall under the jurisdiction of the country. [But see Taylor v Best, 23, LJCP [ns] 89.] And although, in consequence of the minister's independency, no legal process can, in these law-suits, be directly issued against his person, he is nevertheless, by the seizure of the effects belonging to his commerce, indirectly compelled to plead in his own defence. The abuses which would arise from a contrary practice, are evident. What could be expected from a merchant vested with a privilege to commit every kind of injustice in a foreign country? There exists not a shadow of reason for extending the ministerial immunity to things of that nature. If the Sovereign who sends a minister is apprehensive of any inconvenience from the indirect dependency in which his servant thus becomes involved, he has only to lay on him his injunctions against engaging in commerce, an occupation, indeed, which illaccords with the dignity of the ministerial character. ${ }^{48}$

Applying the doctrine expressed by Vattel to the case at hand, Norris R held:

Now if such be the liabilities incurred by an Ambassador, who abuses his public privileges for private purposes, can it be reasonably contended that a Sovereign Prince who is permanently resident in a foreign country, enjoying the full protection of its laws, is exempt from all legal responsibility, when he lays aside as it were, his sovereign character and descends to the level of an ordinary subject, by engaging in mercantile transactions wholly unconnected with his royal station? I think not. Under such circumstances, he may fairly be presumed to have waived, to that extent, his exclusive privileges, and by voluntarily entering into contracts with common men, to have impliedly given his assent to those laws to which all contracting parties are of necessity, answerable;

$48 \quad I d$. at 300. 
for where there is no mutuality of rights and remedies, there can be no legal contract. And as, on the one hand, a Sovereign thus contracting would probably not scruple, or at least would think himself entitled to demand legal redress for a breach of any such contract, so, on the other, he must, on the principles of evenhanded justice, be considered as impliedly acquiescing in the other party's legal right to redress in case of need. Now the instrument on which the present action is founded, is a contract of this description, viz., a promissory note importing upon the face of it, that it is given in consideration of money advanced by the plaintiff to the defendant for the purposes of trade; and for the enforcement of such trading contract, the defendant's effects are in the ordinary course of law, and with the qualification above mentioned, liable, in my opinion, notwithstanding his sovereign character, supposing that to have been satisfactorily proved. ${ }^{49}$

The only case in which an acta jure imperii was deemed to have taken place was JMP Smith v. Sultan of Kedah ${ }^{50}$ heard in Penang in 1906. Here, the plaintiff land concessionaire sought damages against the Sultan of Kedah for an alleged breach of contract when the latter reneged on a promise to transfer land to him. The Court held regardless of whether Sultan of Kedah was an independent sovereign or a dependency of Siam, "a grant of State land by the Sultan of Kedah as Ruler of Kedah, must be taken as a grant of State land by or on behalf of an independent State" and "no foreign country can have the right to interfere with any disposition of its property made by an independent State." ${ }^{11}$ Law J added:

I think every independent State must have the right to dispose of its property including land, in whatever way it sees fit, and that the Courts of no foreign country can have the right to interfere with any disposition of its property made by an independent State. As a rule any attempt at interference would have no effect, and if such $\mathrm{n}$ attempt could be made effectual it would, it seems to me, be a most serious interference with the independence of the State

49 Id. at 300-301.

50 [1906] 10 S.S.L.R. 1.

$51 \quad I d$. at 6. 
where the property was situated, and also be a breach of the comity of nations. ${ }^{52}$

A foreign sovereign automatically attracts immunity provided that the entity of which he or she is the ruler is recognised as a sovereign state by the British government. This point was made patently clear in Lim Guan Teet v. Tunku Akobe ${ }^{53}$ where the Court was asked to consider the status of the defendant Tunku Akobe of Pateh in Sumatra. Wood J held that:

The authorities seem to lay down, that recognition is first necessary, before this Court can hold the defendant exempt. I don't at present see there has been any recognition, but if the occasion require it, will the parties consent to my enquiring of the authorities, if there has been any communication between the Dutch Government and the Crown of England, relative to the independent state of Pateh in Acheen, and if so what? ${ }^{54}$

The Court did not go so far, as the case was dismissed on the basis of fraud committed by the plaintiff. Recognition of a foreign sovereign was accorded in the case of Nairne v. Ahmed Tajudin bin Sultan Zain Noor Rashid (Sultan of Kedah). ${ }^{55}$ In this case, the plaintiff had carried out some mercantile partnership transactions with the Sultan of Kedah and proceeded to sue him in Penang on these transactions which involved a charterparty that sunk off the coast of Cochin China. At the time of the transaction, the Sultan was residing in Penang, but he subsequently returned to his home state of Kedah, a state tributary of Siam. The main task for the Court was to consider the Sultan's objection to being sued in the British courts. This is a long and difficult judgment as a number of separate issues were conflated within it. Maxwell R approached it by asking if the Sultan could be considered a British subject because he was born in Penang. Maxwell $\mathrm{R}$ answered this in the negative, stating that while he may well have been a British subject - and hence amenable to the Court's jurisdiction - at the time of his birth, his subsequent acquisition of independent sovereign status as the ruler of Kedah afforded him immunity. After an extensive consideration of the English case of The King of Hanover $v$ The Duke of

\footnotetext{
$52 \quad I d$.

53 [1808-1884] 1 Ky. 539.

$54 \quad I d$. at 541.

$55 \quad$ [1808-1884] 1 Ky. 145.
} 
Brunswick, ${ }^{56}$ Maxwell held that this about the general rule establishing the immunity of sovereigns that

it appears that the rule is founded on this general consideration, that to require a foreign sovereign to submit to the authority of our Courts would be a violation of immunities necessary to his independence and a hostile aggression on his inviolability. This would be a legitimate ground of offence to him and to all other Princes, and might lead to war; and in the choice of evils, it is better that there should be a failure of justice to an individual, than that the state should be involved in danger. And it appears to me that all the exceptions to the rule turn on the existence of peculiar circumstances which preclude the giving of legitimate offence and the consequent danger. Thus, the sovereign who appeals to a foreign tribunal cannot complain that his sovereign rights are infringed by his being required to answer a cross bill, or a bill of discovery, concerning the same subject matter. So, those rights are not invaded when he is made a party to a suit merely for the purpose of giving him the option of defending his interests already imperilled through his agent. ${ }^{57}$

\section{CONCLUSION}

The major pre-occupation of the courts of the Straits Settlements was in dealing with two key concerns: first, the lack of admiralty jurisdiction to handle offences committed within its territories and with piracy; and second, claims of independent sovereignty that would oust their jurisdiction. Of these two problems, the first was rather more difficult for the Court to handle. The division between common law and admiralty jurisdiction was historical and did not receive sufficient attention in the metropolis. This was further compounded by the fact that the British East India Company, which lasted from 1600 to 1858, functioned as an agent of the British state, but was itself far more concerned with its potency in trade and jurisdiction over maritime matters. The separation between common law and admiralty jurisdictions did not pose a serious a problem in England since both the common law courts and those of the Lord High Admiral were located close to each other. It proved a most inconvenient problem

$\begin{array}{ll}56 & 6 \text { Beav } 1 . \\ 57 & I d . \text { at } 156 .\end{array}$


when the Straits Settlements was being run out of the Bengal Presidency, with only the three Admiralty Courts in Calcutta, Madras, and Bombay exercising exclusive admiralty jurisdiction but with the nearest Court of Judicature in Penang located almost 1500 miles away. The preservation of this historical distinction meant that up till 1837, persons arrested in the waterways (outside the proverbial lower-water extent of land) or on the high seas had to be sent to Calcutta for trial or otherwise set free.

The problem of sovereign immunity was rather less intractable but nonetheless presented the courts with some difficulty. The law that was applied was clear and straightforward: independent sovereigns acting as sovereigns were immune from the Court's jurisdiction. In that sense the distinction between acta jure gestionis and acta jure imperii was established very early on, indeed long before the English courts recognised this distinction in $1977 .{ }^{58}$ This could well be because the Straits Settlements courts adopted the logic of Grotius rather than that of Alberico Gentili in determining the extent of and exceptions to sovereign immunity. Gentili, who held the Regius Professorship in Civil Law at Oxford from 1580 to his death in 1608, published a number of influential international law texts, the most important of which was De Jure Belli Commentationes or Law of War (1589). Of particular relevance to our discussion is his De legationibus, libri tres or Three Books on Embassies (1585). Gentili's works were published in Latin and were not translated into English till the early part of the twentieth century. This may well have been the reason why his position on sovereign immunity was less well-known and accepted in later years. As Przetacznik explains:

The English doctrine of immunity from civil jurisdiction, as that from criminal jurisdiction, also begins with Gentili's Three Books on Embassies. As indicated earlier, A. Gentili based his arguments in the field of the jurisdictional immunity of diplomatic agents in general, and their immunity from civil jurisdiction in particular, on the doctrines of Roman law. Therefore, it seems indispensable to state the rules of the Roman law de legatis. A legatus was exempt from the jurisdiction of the tribunals in Rome as to all actions ex contractu arising out of liabilities incurred before his appointment, and as to all actions ex delicto and criminal proceedings for wrongs done or offenses committed before the same period. The reason of

58 See, Trendtex Trading Corporation v. Central Bank of Nigeria [1977] 2 Q.B. 529 (Court of Appeal). 
the rule was that he might not be disturbed in the performance of his duties, and that the business of the legation might be impeded. For the same reason, and also because he was not liable to be sued, he could not maintain an action ex contractu in those tribunals during the continuance of his office. But for contract or wrong done during the continuance of his office, he was not immune; as to the former, that he might not carry off the property of his creditors without paying for it; as to the latter, because his immunity was forfeit by his own wrong....

... Gentili's concept, which virtually denied the immunity from civil jurisdiction of diplomatic agents, was not accepted by the doctrine of international law. H. Grotius laid down a contrary rule, according to which the movable goods of an ambassador ought to be free from all constraint, whether touching his person or things which are necessary to him, in order that his security may be complete. In the view of the latter, if an ambassador has contracted a debt, he should be asked to pay in a friendly way; if he refuses, the request should go to the one who sent him. Finally, the methods may be used which are customarily used against debtors living outside the country. In this respect, the doctrine of international law followed H. Grotius rather than A. Gentili, as the former's concept was accepted by the most distinguished writers, including such classics as C. Bynkershoek and E. de Vattel. ${ }^{59}$

Emerich de Vattel's Treatise on the Law of Nations, it will be recalled, was cited as authority in the Court of Judicature's 1843 decision in Abdul Wahab bin Mohomat Alli v. Sultan Alli Iskander Shah (Sultan of Johore). ${ }^{60}$ This work, which was first published in 1758, was translated into English just two years later in 1760 and was readily accessible to jurists throughout the English-speaking common law world.

Insofar as the local cases are concerned, it is not, however, clear how much weight the court gave to each respective transaction. For example, the Court had no problem determining that the Sultan of Johore could be sued on a promissory note, but the Sultan of Kedah should be immune when the vessel he owned was destroyed and his business partner sought recompense from him. The main difficulty confronting the Court was in determining which "sovereigns" were independent and whether they were

\footnotetext{
59 See, Franciszek Przetacznik, The History Of The Jurisdictional Immunity Of The Diplomatic Agents In English Law (1978) 7 Anglo-Am L. Rev. 348, at 372-373. 
immune. Historical accounts were often relied upon to determine if the person claiming immunity still had sufficient independence and power to act as a sovereign. Many of the "sovereigns" had in fact been displaced by the British themselves through treaties of cession. Are these former rulers to be dealt with in the same manner as independent sovereigns? Would they be treated differently if they were under the protection of Britain's European rivals, such as Holland?

One thing is certain. The early colonial courts were quite prepared to deal with international legal issues and to deal with them according to the law of nations as they understood it. The sources relied upon by the colonial courts were typically cases decided by the courts in London. They also cited with great approval, important publicists like Emmerich Vattel, Richard Zouche, and Henry Wheaton. These writers, together with home-grown talent like Sir James Fitzjames Stephens provided the necessary intellectual fodder and ballast for the Court to render decisions intelligently, efficaciously, and in line with international practice. 